\title{
Silicate fertilization potentiates the nodule formation and symbiotic nitrogen fixation in soybean ${ }^{1}$
}

\author{
Fábio Steiner ${ }^{2}$, Alan Mario Zuffo ${ }^{3}$, Aécio Bush ${ }^{2}$, Diego Muniz da Silva Santos ${ }^{4}$
}

\section{ABSTRACT}

The application of silicon $(\mathrm{Si})$ to the soil can increase the grain yield of the soybean crop by improving the nitrogen biological fixation, due to its beneficial effect on the Bradyrhizobium-soybean symbiosis. This study aimed to investigate the effect of fertilization with calcium and magnesium silicate on plant growth, root nodulation and nitrogen $(\mathrm{N})$ uptake, in two soybean cultivars [BRS 1074 IPRO (transgenic) and BRS-MG 800A (conventional)], under greenhouse conditions. The application of silicate significantly increased the number of root nodules only for the BRS-MG $800 \mathrm{~A}$, while the positive effects of the silicate addition on nodule size, chlorophyll level and leaf $\mathrm{N}$ concentration were observed in both cultivars. The soybean cultivars show distinct responses to the silicate application, with respect to growth and dry matter yield, being the BRS 1074 IPRO more responsive than the BRS-MG 800A. Therefore, Si may induce the formation of root nodules in soybean plants and lead to significant increases in the nitrogen biological fixation and plant growth. These results highlight that $\mathrm{Si}$ is not only involved in the improvement of plant growth, but it can be also considered a crucial element to improve the symbiotic performance of soybean plants. However, the physiological basis of how and where silicate exerts its influence on nodulation and nitrogen biological fixation still remains unknown.

KEYWORDS: Glycine max (L.) Merrill; nodulation; silicon; chlorophyll.

\section{INTRODUCTION}

Soybean [Glycine $\max (\mathrm{L}$.) Merrill.] is one of the most important crop plants in the world, especially due to the high amount of seed protein (36-40\%) and oil content (18-20\%), and due to its capacity to fix atmospheric nitrogen through symbiosis with soil-

\section{RESUMO}

Adubação silicatada potencializa a formação de nódulos e a fixação biológica de nitrogênio em soja

A aplicação de silício ( $\mathrm{Si}$ ) ao solo pode aumentar o rendimento de grãos da cultura da soja, por melhorar a fixação biológica de nitrogênio, devido ao seu efeito benéfico sobre a simbiose Bradyrhizobium-soja. Objetivou-se investigar o efeito da aplicação de silicato de cálcio e magnésio no crescimento, nodulação e absorção de nitrogênio $(\mathrm{N})$, em duas cultivares de soja [BRS 1074 IPRO (transgênica) e BRS-MG 800A (convencional)], em condições de casa-de-vegetação. A aplicação de silicato aumentou significativamente o número de nódulos apenas para a BRS-MG 800A, enquanto os efeitos positivos da adição de silicato no tamanho do nódulo, nível de clorofila e concentração foliar de $\mathrm{N}$ foram observados em ambas as cultivares. As cultivares de soja têm distinta resposta à aplicação de silicato, em relação ao crescimento e produção de matéria seca, sendo a BRS 1074 IPRO mais responsiva que a BRS-MG 800A. Portanto, o Si pode induzir a formação de nódulos radiculares em plantas de soja e levar a aumentos significativos na fixação biológica de N e no crescimento das plantas. Esses resultados ressaltam que o Si não está envolvido apenas na melhoria do crescimento das plantas, mas, também, pode ser considerado um importante elemento para melhorar o desempenho simbiótico destas. No entanto, a base fisiológica de como e onde o silicato exerce sua influência na nodulação e na fixação biológica de nitrogênio ainda permanece desconhecida.

PALAVRAS-CHAVE: Glycine max (L.) Merrill; nodulação; silício; clorofila.

borne microorganisms (Hungria \& Mendes 2015). Therefore, the use of management practices that can optimize the biological nitrogen fixation and yield performance of the crop are of extreme importance for the agribusiness of the soybean crop in Brazil.

The nitrogen biological fixation in soybean is dependent on an adequate supply of macro and

1. Manuscript received in Feb./2018 and accepted for publication in Jul./2018 (http://dx.doi.org/10.1590/1983-40632018v4851472).

2. Universidade Estadual de Mato Grosso do Sul, Departamento de Agronomia, Cassilândia, MS, Brasil.

E-mail/ORCID: steiner@uems.br/0000-0001-9091-1737, busch088@gmail.com/0000-0002-7843-9158.

3. Universidade Federal de Mato Grosso do Sul, Departamento de Agronomia, Chapadão do Sul, MS, Brasil. E-mail/ORCID: alan_zuffo@hotmail.com/0000-0001-9704-5325.

4. Universidade Estadual Paulista, Faculdade de Ciências Agrárias e Veterinárias, Jaboticabal, SP, Brasil. E-mail/ORCID: diegomunizbbr@gmail.com/0000-0003-3331-3014. 
micronutrients. These elements are not only essential for the symbiotic interaction, but also for the host plant and its microbial partner (Nelwamondo \& Dakora 1999). Regarding the effect of silicate nutrition, there is evidence that silicon ( $\mathrm{Si}$ ) may have an influence on the Bradyrhizobium-soybean symbiosis (Castro \& Crusciol 2015) and, therefore, has the capacity to improve the fixation of atmospheric nitrogen $\left(\mathrm{N}_{2}\right)$ by rhizobia.

Calcium and magnesium silicate can be used as a corrective of soil acidity (Castro \& Crusciol 2015, Sarto et al. 2015) and as a Si source (Ruppenthal et al. 2016). The application of Si shows beneficial effects on the growth and yield of several crops, especially those considered as Si-accumulating plants, such as rice, sugarcane, maize, sorghum and wheat (Hattori et al. 2005, Kaya et al. 2006, ZanãoJúnior et al. 2010, Sarto et al. 2015, Camargo et al. 2017). However, dicotyledonous species, considered as non-Si accumulating plants, such as tomato, cucumber, cowpea, cotton, potato and soybean, have also responded positively to the soil-applied $\mathrm{Si}$ (Nelwamondo \& Dakora 1999, Toresano-Sánchez et al. 2012, Ferraz et al. 2014, Pilon et al. 2014, Wang et al. 2015, Pascual et al. 2016).

Responses to Si fertilization may be potentiated when crops are exposed to various abiotic and biotic stress conditions (Coskun et al. 2016). The beneficial effects of $\mathrm{Si}$ on plant growth have been attributed to the increase in the chlorophyll content and photosynthetic capacity, reduction in the transpiration rate and increase in the nutrient uptake (Ma \& Yamaji 2006, Ferraz et al. 2014, Coskun et al. 2016). These effects are mainly attributed to the high accumulation of silica on the surface of leaves and stems (Ma \& Yamaji 2006) and other mechanisms.

The beneficial effect of $\mathrm{Si}$ on soybean nodulation is related to its role in modulating the metabolism of phenolic compounds in plants (Zhang et al. 2013). Silicon is involved in the synthesis or in biochemical processes of isoflavonoids (Bockhaven et al. 2013), and, therefore, it influences on the expression of nod genes related to the formation of root nodules in leguminous plants (Nelwamondo \& Dakora 1999). In addition, the isoflavonoids released by legume roots also serve as chemo-attractants for the nitrogen-fixing bacteria (Bradyrhizobium sp.) (Eckardt 2006).

Therefore, Si has the potential to increase the nodulation, growth and yield of leguminous plants.
Indeed, Nelwamondo \& Dakora (1999) reported that applying Si resulted in a significant increase in the number of root nodules, nodule dry matter and $\mathrm{N}$ fixed by cowpea plants (Vigna unguiculata L. Walp.) inoculated with Bradyrhizobium. Lopes et al. (2011) also found that the Si application resulted in increased nodulation, root dry matter production and nutrient uptake of Stylosanthes guianensis (Aubl.) Sw. cv. Mineirão. Kurdali et al. (2013) concluded that $\mathrm{Si}$ is not only involved in growth improvement and in maintaining the water status, but it also can be considered a crucial element for the symbiotic performance of chickpea plants (Cicer arietinum L.). However, the effect of Si application for improving root nodulation and growth of soybean plants is still unknown.

Thus, this research was carried out to investigate the effects of fertilization with calcium and magnesium silicate on growth, nodulation and $\mathrm{N}$ uptake, in two soybean cultivars grown in a greenhouse.

\section{MATERIAL AND METHODS}

The experiment was conducted in a greenhouse in Cassilândia, Mato Grosso do Sul state, Brazil $\left(19^{\circ} 05^{\prime} 20^{\prime \prime} \mathrm{S}, 51^{\circ} 48^{\prime} 24^{\prime \prime} \mathrm{W}\right.$ and altitude of $\left.510 \mathrm{~m}\right)$, from October to December 2017. The environmental conditions during the experiment were: minimum and maximum air temperatures of $19.4{ }^{\circ} \mathrm{C}$ and $36.7{ }^{\circ} \mathrm{C}$, respectively; average air relative humidity of $72 \%( \pm 5 \%)$ and midday photosynthetic photon flux density of $980 \mu \mathrm{mol} \mathrm{m} \mathrm{m}^{-2} \mathrm{~s}^{-1}\left( \pm 235 \mu \mathrm{mol} \mathrm{m}^{-2} \mathrm{~s}^{-1}\right)$.

The soil used in the experiment was a Si-deficient typical Red-Yellow Latosol (Typic Hapludox), collected from a Savannah area, with $210 \mathrm{~g} \mathrm{~kg}^{-1}$ of clay, $60 \mathrm{~g} \mathrm{~kg}^{-1}$ of silt and $730 \mathrm{~g} \mathrm{~kg}^{-1}$ of sand; $\mathrm{pH}\left(\mathrm{CaCl}_{2}\right)=5.0 ; \mathrm{P}\left(\right.$ Mehlich-1) $=32 \mathrm{mg} \mathrm{dm}^{-3}$; $\mathrm{K}\left(\right.$ Mehlich-1) $=85 \mathrm{mg} \mathrm{dm}^{-3} ; \mathrm{Al}^{3+}=0.0 \mathrm{cmol}_{\mathrm{c}} \mathrm{dm}^{-3}$; $\mathrm{Ca}^{2+}=3.7 \mathrm{cmol}_{\mathrm{c}} \mathrm{dm}^{-3} ; \mathrm{Mg}^{2+}=1.6 \mathrm{cmol}_{\mathrm{c}} \mathrm{dm}^{-3} ; \mathrm{H}^{+}+$ $\mathrm{Al}^{3+}=2.6 \mathrm{cmol}_{\mathrm{c}}^{\mathrm{c}} \mathrm{dm}^{-3} ; \mathrm{CEC}=8.1 \mathrm{cmol}_{\mathrm{c}}^{\mathrm{c} \mathrm{dm}^{-3}}$; base saturation $=68 \%$; and organic matter $=20 \mathrm{~g} \mathrm{~kg}^{-1}$. The concentration of available $\mathrm{Si}$ (extraction in $\mathrm{CaCl}_{2}$ ) was $8.6 \mathrm{mg} \mathrm{dm}^{-3}$, which can be considered very low and adequate for an experiment aiming to test the $\mathrm{Si}$ application efficiency. The soil was then placed in $8 \mathrm{~L}$ plastic pots and fertilized with $250 \mathrm{mg} \mathrm{kg}^{-1}$ of $\mathrm{P}$ as simple superphosphate $\left(18 \%\right.$ of $\mathrm{P}_{2} \mathrm{O}_{5}, 25 \%$ of $\mathrm{CaO}$ and $12 \%$ of $\mathrm{S}), 80 \mathrm{mg} \mathrm{kg}^{-1}$ of $\mathrm{K}$ as potassium chloride $\left(60 \%\right.$ of $\left.\mathrm{K}_{2} \mathrm{O}\right)$ and $30 \mathrm{mg} \mathrm{kg}^{-1}$ of $\mathrm{S}$ as 
gypsum (13\% of S and $18 \%$ of $\mathrm{Ca}$ ). Each plastic pot was filled with $10 \mathrm{~kg}$ of air-dried soil sieved in $4.0 \mathrm{~mm}$ mesh. Fertilizer was applied according to the recommendations for greenhouse crops by Novais et al. (1991), with modifications. The exceptions were the omissions of $\mathrm{N}$ and micronutrient applications.

The experiment was arranged in a randomized block design, using two Si levels $\left(0 \mathrm{mg} \mathrm{kg}^{-1}\right.$ or $200 \mathrm{mg} \mathrm{kg}^{-1}$ ) and two soybean cultivars [BRS 1074 IPRO (transgenic, Intacta RR2 PRO ${ }^{\mathrm{TM}}$, indeterminate growth habit, cycle of 108-115 days, maturation group 7.4) and BRS-MG 800A (conventional, determinate growth habit, cycle of 120-125 days, maturation group 8.0)], considering a $2 \times 2$ factorial arrangement, with six replications. Calcium and magnesium silicate, used as the $\mathrm{Si}$ source [AgroSilício Plus $^{\circledR}$, Agronelli Insumos Agrícolas, Timóteo, MG, BRA], was composed of $10.5 \%$ of $\mathrm{Si}, 25 \%$ of $\mathrm{Ca}$ and $6 \%$ of $\mathrm{Mg}$. Calcium and magnesium silicate was incorporated into each pot, at the rate of $1.9 \mathrm{~g} \mathrm{~kg}^{-1}$ of soil (equivalent to $200 \mathrm{mg} \mathrm{kg}^{-1}$ of $\mathrm{Si}, 475 \mathrm{mg} \mathrm{kg}^{-1}$ of $\mathrm{Ca}$ and $114 \mathrm{mg} \mathrm{kg}^{-1}$ of $\mathrm{Mg}$ ), at seven days before the soybean sowing. The application rate of silicate used in this study was based on investigations carried out with other crops (Lopes et al. 2011, Kurdali et al. 2013, Sarto et al. 2015, White et al. 2017), where the application of $150-250 \mathrm{mg} \mathrm{kg}^{-1}$ of Si resulted in the best plant growth rates.

The soybean seeds [Glycine max L. (Merrill)] were previously inoculated with Bradyrhizobium japonicum, using the commercial liquid inoculant Simbiose Nod Soja ${ }^{\circledR}$ (Simbiose: Biological Agrotechnology), containing SEMIA 5079 and SEMIA 5080 strains (minimum concentration of $7.2 \times 10^{9}$ viable cells $\mathrm{mL}^{-1}$ ), at a rate of $3 \mathrm{~mL} \mathrm{~kg}^{-1}$ of seeds. Six soybean seeds were then sown in plastic pots containing sandy soil and, at seven days after emergence, seedlings were thinned down to two per pot. The soil water content was monitored daily and maintained close to the field capacity with daily irrigations.

At full flowering ( $R_{2}$ phenological stage), the plants were harvested and then the number of trifoliate leaves, plant height, stem diameter, number of nodules per plant and shoot, root and nodule dry matter were measured. The roots were put in a $1.0 \mathrm{~mm}$ mesh sieve and washed under running tap water to remove the adhered soil. The nodules were gently removed, washed and counted. The plants were then separated into leaves, stems, roots and nodules, oven dried for three days $\left(65^{\circ} \mathrm{C}\right)$ and then weighed. The results were expressed in $\mathrm{g} \mathrm{plant}^{-1}$. The leaf area $\left(\mathrm{LA} ; \mathrm{dm}^{2}\right.$ plant $\left.^{-1}\right)$ was determined using the equation proposed by Benincasa (2003): $\mathrm{LA}=[(\mathrm{LAs} \times \mathrm{LTDM}) / \mathrm{DMs}]$, where $L A s$ is the leaf area of the collected sample, LTDM the leaf total dry matter and $D M s$ the dry matter of the collected sample.

The relative chlorophyll index was measured by a chlorophyll meter Apogee model MC-100 (Apogge Instruments Inc., Logan, UT, USA), with six measurements in two plants per pot, at the third trifoliolate leaf totally expanded, between the edge and the main nerve of the leafblade. After measuring the relative chlorophyll index, the trifoliolate leaves were collected for the determination of $\mathrm{N}$ and $\mathrm{Si}$ concentrations. The leaf samples were dried for three days $\left(55^{\circ} \mathrm{C}\right)$ and ground in a Willey mill. $\mathrm{N}$ was determined by sulfuric acid digestion and vapor distillation by the semi-micro Kjeldahl method (Embrapa 2009) and Si by hydrogen peroxide and sodium hydroxide digestion, determined by colorimetry (Korndörfer et al. 2004).

The leaf area ratio (LAR), specific leaf area (SLA) and leaf weight ratio (LWR) were determined from the leaf area values (LA) expressed in $\mathrm{dm}^{2}$ plant $^{-1}$, total dry matter (TDM) and leaf dry matter (LDM), both expressed in $\mathrm{g} \mathrm{plant}^{-1}$, using the following equations (Benincasa 2003): LAR $\left(\mathrm{dm}^{2} \mathrm{~g}^{-1}\right)=\mathrm{LA} /$ TDM; SLA $\left(\mathrm{dm}^{2} \mathrm{~g}^{-1}\right)=\mathrm{LA} / \mathrm{LDM}$; and LWR $\left(\mathrm{g} \mathrm{g}^{-1}\right)=$ LDM/TDM.

The data normality was previously tested by the Kolmogorov-Smirnov test at $5 \%$ of significance and then the data were submitted to analysis of variance (Anova), and the averages for silicon fertilization and soybean cultivars were compared by the F test, at the 0.05 level of significance. The analyses were performed using the Sisvar (version 5.3) software for Windows (Statistical Analysis Software, UFLa, Lavras, MG, BRA).

\section{RESULTS AND DISCUSSION}

A summary of the analysis of variance for the measurements of mineral nutrition, nodulation, growth and dry matter partitioning of soybean plants is shown in Table 1. The results of the analysis of variance showed significance $(p<0.05)$ for the main effects of soybean cultivars and $\mathrm{Ca}$ and $\mathrm{Mg}$ silicate application, as well as interaction for most the traits measured 
(Table 1). The significant interaction between the main effects of cultivars and silicate application for most of the evaluated traits indicates that soybean cultivars have different responses, regarding $\mathrm{Ca}$ and $\mathrm{Mg}$ silicate fertilization or non-fertilization.

The application of $\mathrm{Ca}$ and $\mathrm{Mg}$ silicate increased the number of root nodules of the BRSMG 800 A cultivar at $82 \%$, if compared to the nonsilicate fertilization, whereas the number of nodules of the BRS 1074 IPRO was not significantly affected $(p>0.05)$ by the Si supply (Figure 1A). Although the transgenic cultivar (BRS 1074 IPRO) did not respond positively to the silicate application, with an increase in the number of nodules, it presented a nodulation similar to the conventional cultivar (BRS-MG 800A), with the application of silicate. These results report the high nodulation potential of the transgenic soybean cultivar, when compared to the conventional one.

The positive response in the formation of root nodules in the BRS-MG 800A (conventional) cultivar may be related to the beneficial effect of $\mathrm{Si}$ on the biosynthesis and metabolism of phenolic compounds such as isoflavonoid (Zhang et al. 2013). The isoflavonoids released by legume roots have been reported to play multiple roles at distinct stages of the nodulation process, especially because it acts as chemo-attractants of Bradyrhizobium and regulates the nod genes expression (Nelwamondo \& Dakora 1999, Eckardt 2006).

The $\mathrm{Ca}$ and $\mathrm{Mg}$ silicate application resulted in the greater dry mass of nodules per plant (Figure 1B) and average dry mass per nodule (Figure 1C), in both soybean cultivars, if compared to non-silicate fertilization. The percent increments for nodule size in the treatments with silicate were $38 \%$ and $76 \%$, respectively for the BRS-MG 800A and BRS 1074 IPRO cultivars, when compared to the unfertilized control with silicate (Figure 1C). These results indicated that the application of silicate improved the nodulation of both soybean cultivars, resulting in higher $\mathrm{N}$ biological fixation (Figure 2), and also improving plant growth (Figure 3).

The beneficial effect of Si application on the nodulation process of leguminous plants has been reported in other crops. In cowpea plants (Vigna unguiculata L. Walp.) inoculated with Bradyrhizobium strain CB756, Nelwamondo \& Dakora (1999) showed that the Si supply significantly increased the number of root nodules and nodule dry matter. In stylo plants [Stylosanthes guianensis (Aubl.) Sw. var. guianensis], Lopes et al. (2011) also found that the silicate application improved the root nodulation. Kurdali et al. (2013) state that $\mathrm{Si}$ is a crucial element for the symbiotic process, especially for potentiating the nodule formation in chickpea plants (Cicer arietinum L.). Positive effects of Si supply on nodulation of leguminous plants are due to its role in regulating the metabolism of phenolic compounds in plants (Zhang et al. 2013). According to Bockhaven et al. (2013), Si is involved in the synthesis or in biochemical processes of isoflavonoids, and these compounds induce the formation of root nodules by different mechanisms (Nelwamondo \& Dakora 1999, Eckardt 2006).

The silicate application resulted in the greater relative chlorophyll index and leaf concentrations of $\mathrm{N}$ and $\mathrm{Si}$ in both soybean cultivars (Figure 2). The

Table 1. Summary of the analysis of variance for the measurements of nodulation, mineral nutrition, growth and dry matter partitioning of soybean plants, as affected by $\mathrm{Ca}$ and $\mathrm{Mg}$ silicate fertilization.

\begin{tabular}{|c|c|c|c|c|c|c|c|c|}
\hline \multirow{2}{*}{ Causes of variation } & \multicolumn{8}{|c|}{ Probability $>$ F } \\
\hline & NNP & NDM & MPN & RCI & $\mathrm{N}$ & $\mathrm{Si}$ & $\mathrm{PH}$ & NTL \\
\hline Cultivar (C) & $<0.000$ & $<0.000$ & $<0.000$ & 0.002 & 0.008 & 0.175 & $<0.000$ & $<0.000$ \\
\hline Silicate (Si) & $<0.000$ & $<0.000$ & $<0.000$ & $<0.000$ & $<0.000$ & $<0.000$ & $<0.000$ & $<0.000$ \\
\hline $\mathrm{C} \times \mathrm{Si}$ & $<0.000$ & $<0.000$ & 0.003 & 0.005 & 0.011 & 0.812 & $<0.000$ & 0.452 \\
\hline $\mathrm{CV}(\%)$ & 5.980 & 6.020 & 8.190 & 11.070 & 3.260 & 6.510 & 3.460 & 6.870 \\
\hline Causes of variation & $\mathrm{SD}$ & LA & SDM & RDM & TDM & SLA & LAR & LWR \\
\hline Cultivar (C) & 0.230 & $<0.000$ & $<0.000$ & $<0.000$ & $<0.000$ & $<0.000$ & $<0.000$ & $<0.000$ \\
\hline Silicate (Si) & 0.002 & $<0.000$ & $<0.000$ & $<0.000$ & $<0.000$ & $<0.000$ & 0.099 & $<0.000$ \\
\hline$\underline{\mathrm{C} \times \mathrm{Si}}$ & $<0.000$ & 0.006 & $<0.000$ & $<0.000$ & $<0.000$ & 0.046 & 0.011 & 0.762 \\
\hline CV (\%) & 9.250 & 8.010 & 7.010 & 6.240 & 6.590 & 5.210 & 4.130 & 3.690 \\
\hline
\end{tabular}

NNP: number of nodules per plant; NDM: nodule dry mass; MPN: mass per nodule; RCI: relative chlorophyll index; N: foliar nitrogen concentration; Si: foliar silicon concentration; PH: plant height; NTL: number of trifoliate leaves; SD: stem diameter; LA: leaf area; SDM: shoot dry matter; RDM: root dry matter; TDM: total dry matter; SLA: specific leaf area; LAR: leaf area ratio; LWR: leaf weight ratio. 


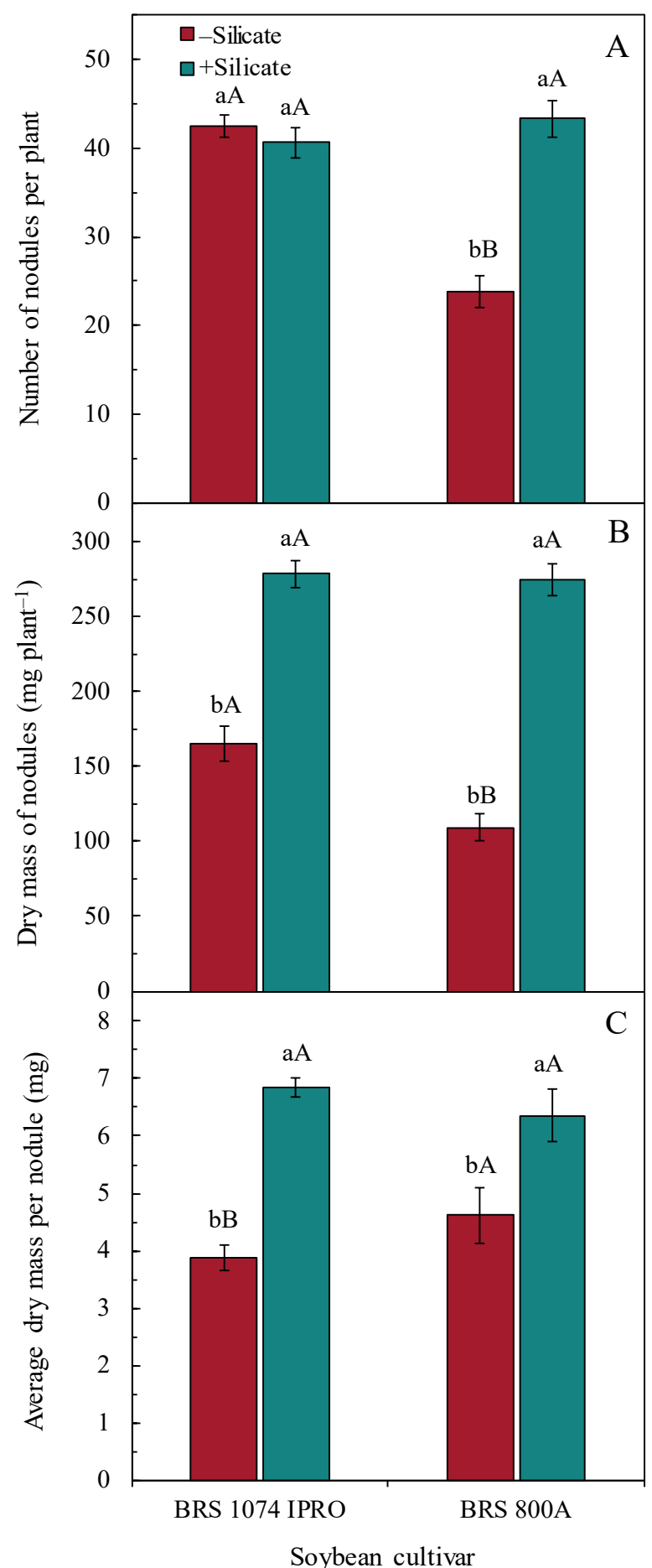

Figure 1. Effect of soil fertilization (+silicate) and nonfertilization (-silicate) with calcium silicate on number of nodules per plant (A), dry mass of nodules (B) and average dry mass per nodule (C), in two soybean cultivars, under well watering conditions. Bars followed by the same lower-case letter between the silicate treatments or the same upper-case letter, for the two soybean cultivars, are not significantly different by the $F$ test at 0.05 of significance. Data refer to mean values $(n=6) \pm$ standard error.

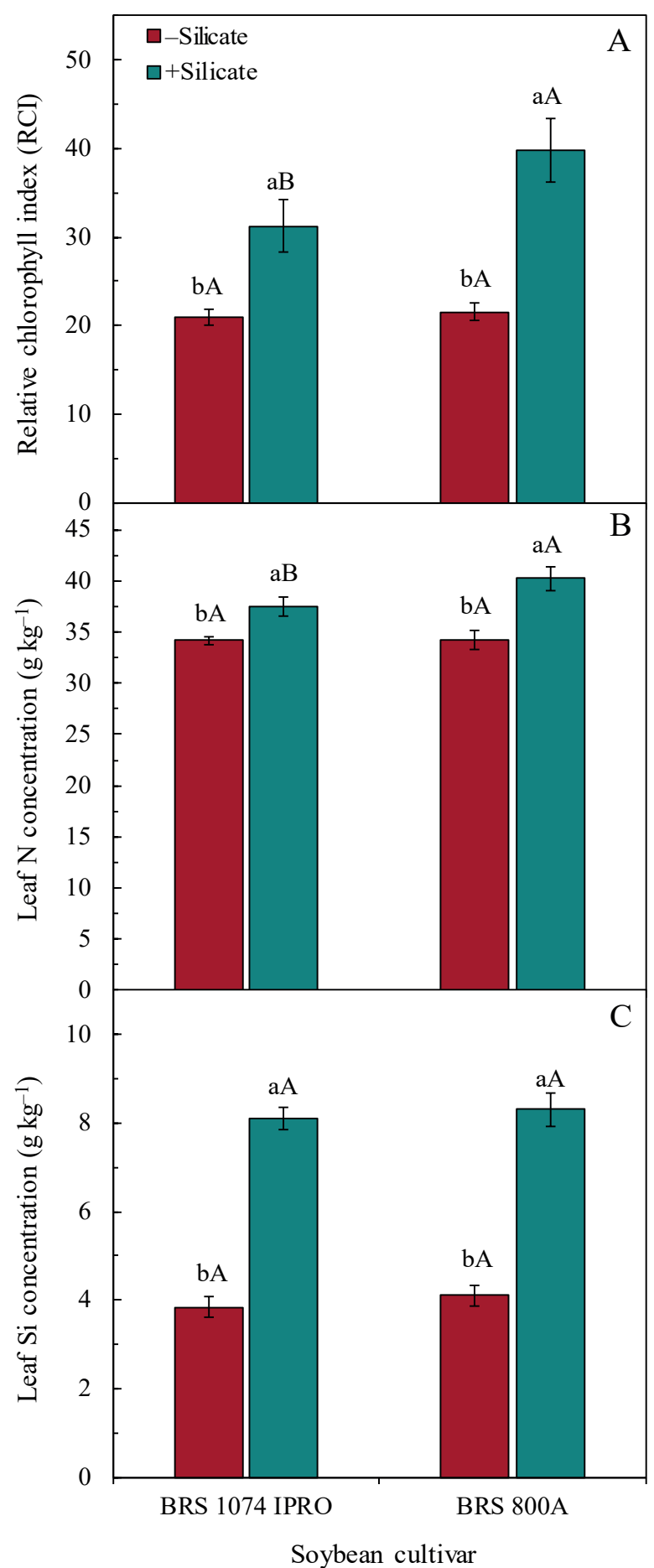

Figure 2. Effect of soil fertilization (+silicate) and nonfertilization (-silicate) with calcium silicate on relative chlorophyll index (A), nitrogen concentration (B) and silicon (C) in the leaves of two soybean cultivars, in well watering conditions. Bars followed by the same lower-case letter between the silicate treatment or the same upper-case letter, for the two soybean cultivars, are not significantly different by the $\mathrm{F}$ test at 0.05 of significance. Data refer to mean values $(n=6) \pm$ standard error. 
silicate application resulted in an increase of $49 \%$ and $85 \%$ in the chlorophyll levels (Figure 2A) and 10\% and $18 \%$ in the leaf $\mathrm{N}$ concentration (Figure 2B), respectively for the BRS 1074 IPRO and BRS-MG 800A cultivars, if compared to the unfertilized control with silicate. These results confirmed the hypothesis that Si has a beneficial effect, regarding chlorophyll. Similarly, Silva et al. (2012) reported that Si resulted in an increase in the chlorophyll level of two tomato cultivars (Lycopersicon esculentum L.). Xie et al. (2014) applied $750 \mathrm{~kg} \mathrm{ha}^{-1}$ of silicate and also observed chlorophyll levels $20 \%$ higher in maize plants. In a study made by Hattori et al. (2005), a marked Si-induced enhancement in photosynthesis and chlorophyll fluorescence was reported in sorghum plants [Sorghum bicolor (L.) Moench], under water deficit conditions.

The beneficial effect of Si on chlorophyll level has been attributed to the accumulation of silica on the tissue stirface (Ma \& Yamaji 2006), which changes the architecture of the plants and keeps the leaves more exposed to light. The greater exposure of the leaves to light induces a higher photosynthetic rate and a greater synthesis of total chlorophyll, thus interfering in the production of chlorophyll $a$ and $b$, confirming the results reported by Locarno et al. (2011) in rose plants and by Silva et al. (2013) in strawberry plants.

The positive effect of silicate fertilization on leaf $\mathrm{N}$ concentration in both cultivars (Figure $2 \mathrm{~B}$ ) may be explained due to the improvement of the root nodulation of soybean plants and higher $\mathrm{N}$ biological fixation (Figure 1). In addition, the higher $\mathrm{N}$ concentration in the leaves resulted in the higher chlorophyll synthesis in the soybean plants (Figure 2A). However, some studies have reported that the Si source application has not been sufficient to enhance the $\mathrm{N}$ level of plants. Freitas et al. (2015) reported that application rates of $50-120 \mathrm{mg} \mathrm{kg}^{-1}$ of $\mathrm{Si}$ did not result in a significant effect on the N concentration in rice leaves. Similarly, the soybean leaf $\mathrm{N}$ concentration was not significantly affected by application rates of $50-200 \mathrm{mg} \mathrm{kg}^{-1}$ of $\mathrm{Si}$ (Ruppenthal et al. 2016).

As expected, the silicate source application significantly increased the leaf Si concentration of the soybean plants (Figure 2C). The silicate application resulted in increases of $110 \%$ and $102 \%$ in the leaf Si concentration, respectively for the BRS 1074 IPRO and BRS-MG 800A cultivars, when compared to the unfertilized control with silicate. These results are due to the fact that the silicate application has increased the availability of this element in the soil and confirm the evidence that soybean, which is considered as a non-Si accumulating plant, also has a great capacity to translocate the $\mathrm{Si}$ absorbed by roots to the shoot, especially to the leaves. Indeed, the $\mathrm{Si}$ absorbed by root cells as monosilicic acid $\left(\mathrm{H}_{4} \mathrm{SiO}_{4}\right)$ is deposited into leaf epidermal cells (Ma \& Yamaji 2006). The significant increase in the leaf Si concentration, with the application of silicate, also has been reported in other leguminous plants, such as cowpea (Nelwamondo \& Dakora 1999) and soybean (Ruppenthal et al. 2016).

The soybean cultivars have distinct responses to the application of $\mathrm{Ca}$ and $\mathrm{Mg}$ silicate, with respect to growth and dry matter yield (Figure 3 ). A positive response of the silicate fertilization to the soil on the BRS 1074 IPRO (transgenic) cultivar was observed for all growth traits measured, except for root dry matter (Figure 3). On the other hand, the silicate application only resulted in a positive effect for the number of trifoliolate leaves (Figure 3B) and leaf area (Figure 3D) on the BRS-MG 800A cultivar, whereas the plants fertilized with silicate had lower root dry matter, if compared to the unfertilized control with silicate (Figure 3F). These results indicate that the $\mathrm{Ca}$ and $\mathrm{Mg}$ silicate application has the potential to improve the growth and dry matter accumulation of soybean plants, but these effects depend on the cultivar, being the transgenic cultivar more responsive to the silicate fertilization.

The lower root dry matter yield with silicate fertilization, in the conventional soybean cultivar (Figure 3F), may be related to the beneficial effect of silicate addition on increasing the number and size of root nodules (Figure 1). This increased nodulation results in a greater number of root drains, therefore reducing the availability of photoassimilates that could be used for root growth. Nodulation and biological nitrogen fixation are highly energetic physiological processes, and symbiotic bacteria may use $10-30 \%$ of the total net of photoassimilates produced by the host plant (Schubert \& Ryle 1980).

The higher growth and dry matter yield of plants fertilized with $\mathrm{Ca}$ and $\mathrm{Mg}$ silicate, especially for the BRS 1074 IPRO cultivar, may be related to the effects of Si in the plant metabolism and morphology. Silicon alleviates the nutritional disorders of higher plants by being involved in the plant metabolic or physiological and/or structural activity (Coskun et 
al. 2016). Silicon can also suppress the activity of certain enzymes, particularly invertase, resulting in a greater sucrose production in plants (Coskun et al. 2016). Therefore, Si has been reported to increase the dry matter and length of shoot and roots, especially when supplied to roots. Indeed, Meena et al. (2014) reported that the Si application resulted in a higher sugar production in sugarcane,
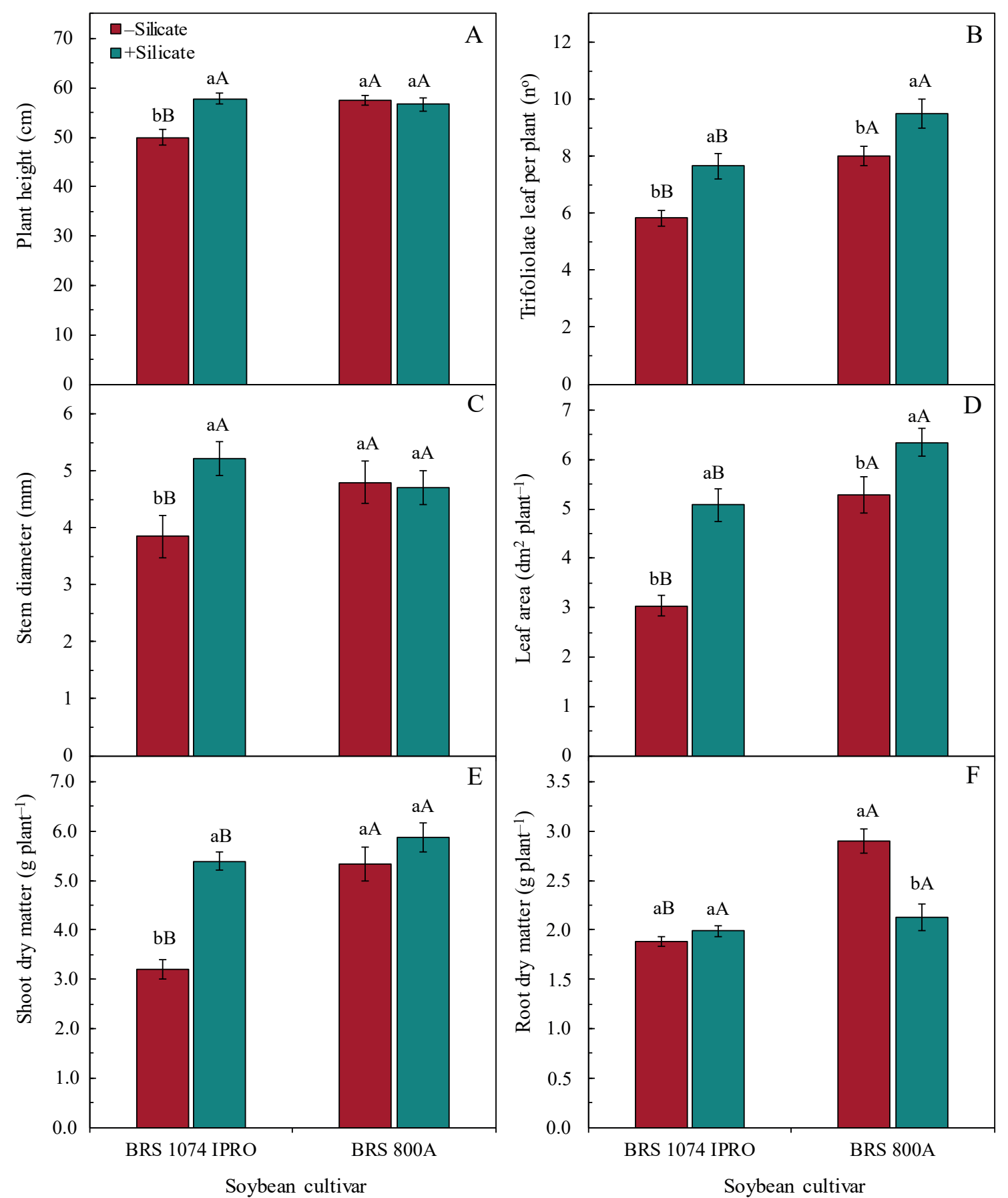

Figure 3. Effect of soil fertilization (+silicate) and non-fertilization (-silicate) with calcium silicate on plant height (A), number of trifoliolate leaves (B), stem diameter (C), leaf area (D), shoot dry matter (E) and root dry matter (F) of two soybean cultivars, in well watering conditions. Bars followed by the same lower-case letter between the silicate treatments or the same upper-case letter, for the two soybean cultivars, are not significantly different by the $\mathrm{F}$ test at 0.05 of significance. Data refer to mean values $(n=6) \pm$ standard error. 
and the reduction of phosphatase provided a greater supply of essential high energy precursors needed for optimum plant growth. Pascual et al. (2016) reported that the $\mathrm{Si}$ addition to the nutrient solution led to an enhancement in the soybean plant growth. Similarly, Kurdali et al. (2013) reported that the application of Si can increase the dry matter yield of chickpea plants in well-watered conditions and improve the growth under drought conditions by maintaining the water status of plants. In this case, Si ensures a high assimilatory capability, thickening the leaves that are beneficial to reduce the loss of water by transpiration (Meena et al. 2014). Therefore, the application of silicate to the soil may increase the grain yield of the soybean crop in many agricultural areas around the world.

The $\mathrm{Ca}$ and $\mathrm{Mg}$ silicate application resulted in higher values for leaf area ratio (Figure 4B) and leaf weight ratio (Figure 4C) of both soybean cultivars, if compared to the unfertilized control with silicate, whereas the specific leaf area in both cultivars was not significantly affected $(\mathrm{p}>0.05)$ by the silicate addition (Figure 4A).

Specific leaf area is an important morphological characteristic of the plant that determines the new leaf area to be deployed for each unit of biomass produced, and has been widely used as an indirect measure of leaf thickness (Benincasa 2003). Any storage of extra carbohydrate in the leaves, or any reallocation of biomass to thicker leaves, would tend to increase the leaf mass more than leaf area, thereby decreasing the specific leaf area. In this study, the silicate fertilization could be expected to result in thickening the leaves (i.e., lower specific leaf area) in various crops, since this element has been reported to accumulate in the leaf epidermal cell walls (Meena et al. 2014). In a study made by Gong et al. (2003), it was found that wheat plants grown in pots with $\mathrm{Si}$ applied before sowing had lower specific leaf area, if compared to those without Si applied under drought stress conditions. This demonstrates that the leaves of stressed plants growing in pots with applied $\mathrm{Si}$ were thicker, when compared to those without Si. However, these effects were not reported in this study, under well-watering conditions.

The application of $\mathrm{Ca}$ and $\mathrm{Mg}$ silicate increases the leaf area ratio and leaf weight ratio of soybean plants by $15 \%$ and $16 \%$ for the BRS 1074 IPRO cultivar, and by $23 \%$ and $17 \%$ for the BRS-MG $800 \mathrm{~A}$ cultivar, respectively, relatively to plants unfertilized

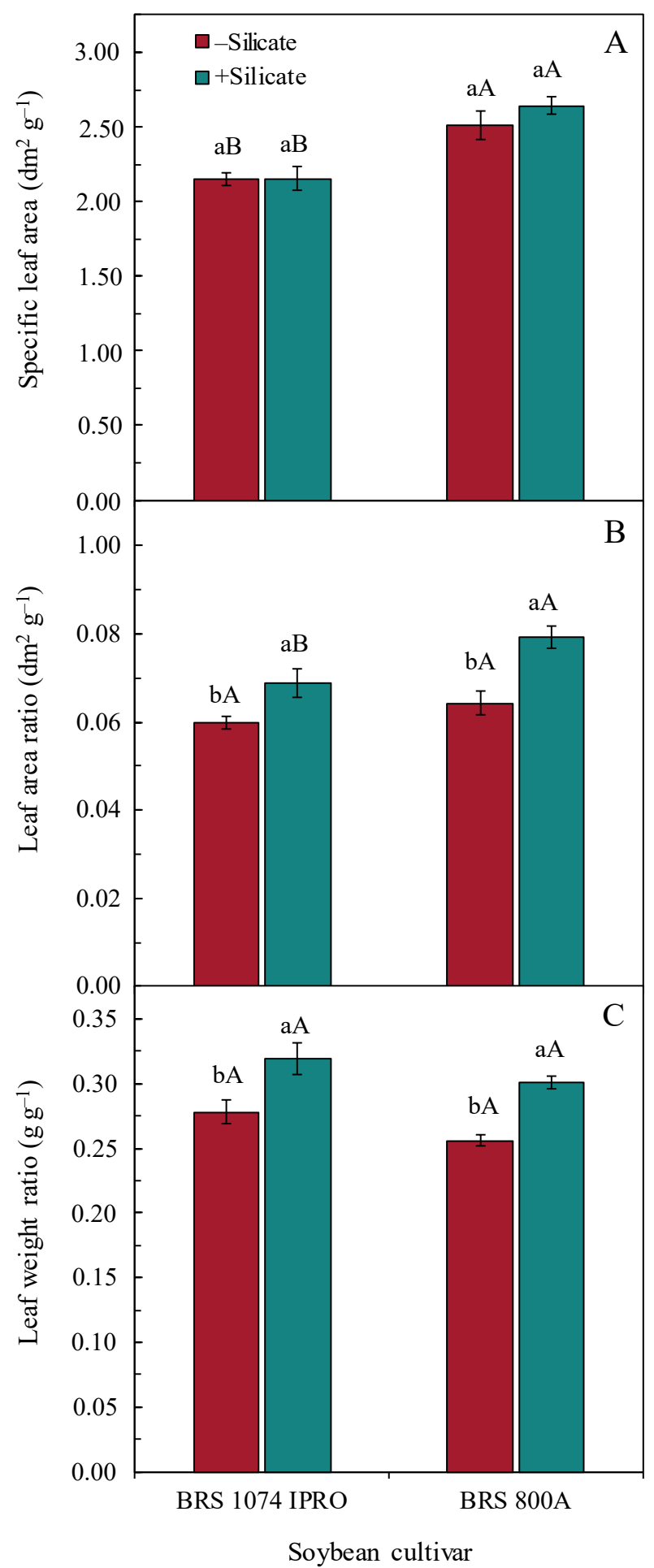

Figure 4. Effect of soil fertilization (+silicate) and non-fertilization (-silicate) with calcium silicate on specific leaf area (A), leaf area ratio (B) and leaf weight ratio (C) of two soybean cultivars, under well-watering conditions. Bars followed by the same lower-case letter between the silicate treatments or the same upper-case letter, for the two soybean cultivars, are not significantly different by the $F$ test at 0.05 of significance. Data refer to mean values $(n=6) \pm$ standard error. 
with silicate (Figures 4B and 4C). Similarly, Gong et al. (2003) also verified that wheat plants fertilized with Si had a greater leaf weight ratio and leaf area ratio, if compared to those without $\mathrm{Si}$ applied. The leaf area ratio represents the photosynthetic surface area per unit dry mass of a plant, and it is a measure of the efficiency with which a plant deploys its photosynthetic resources (Benincasa 2003). In turn, the leaf weight ratio represents the fraction of dry mass not exported from leaves to the other organs of the plant (Benincasa 2003). Therefore, the increase of leaf area ratio and leaf weight ratio with the $\mathrm{Si}$ addition indicate that there was a greater allocation of photoassimilates to leaves, in detriment to the other organs of the plants, such as stem and roots. Subsequently, with the progress of the crop cycle to the reproductive stage, these photoassimilates stored initially in the leaves are then translocated to the soybean pods and grains.

In summary, the results presented here demonstrate that, though not essential for soybean growth, silicon is important for the symbiotic process in this species. However, how and where silicon exerts its influence on nodulation and $\mathrm{N}_{2}$ fixation is yet to be determined.

\section{CONCLUSIONS}

1. Calcium and magnesium silicate fertilization has stimulating effects on the formation and size of the root nodules of soybean plants, improving the biological nitrogen fixation, nitrogen level and relative chlorophyll index, in leaves of the BRS 1074 IPRO (transgenic) and BRS-MG 800A (conventional) cultivars;

2. The soil fertilization with calcium and magnesium silicate has the potential to improve the plant growth, dry matter yield, leaf area, leaf area ratio and leaf weight ratio of soybean plants, but these effects depend on the cultivar, being the transgenic cultivar more responsive to the silicate fertilization.

\section{REFERENCES}

BENINCASA, M. M. P. Análise de crescimento de plantas: noções básicas. Jaboticabal: Funep, 2003.

BOCKHAVEN J. et al. Towards establishing broadspectrum disease resistance in plants: silicon leads the way. Journal of Experimental Botany, v. 64, n. 5, p. 12811293, 2013.
CAMARGO, M. S. et al. Silicon fertilization reduces the deleterious effects of water deficit in sugarcane. Journal of Soil Science and Plant Nutrition, v. 17, n. 1, p. 99-111, 2017.

CASTRO, G. S. A.; CRUSCIOL, C. A. C. Effects of surface application of dolomitic limestone and calciummagnesium silicate on soybean and maize in rotation with green manure in a tropical region. Bragantia, v. 74, n. 3, p. 311-321, 2015.

COSKUN, D. et al. The role of silicon in higher plants under salinity and drought stress. Frontiers in Plant Science, v. 7, n. 1072, 2016. Available at: <https://doi. org/10.3389/fpls.2016.01072>. Access on: 05 Jan. 2018.

ECKARDT, N. A. The role of flavonoids in root nodule development and auxin transport in Medicago truncatula. The Plant Cell, v. 18, n. 7, p. 1539-1540, 2006.

EMPRESA BRASILEIRA DE PESQUISA AGROPECUÁRIA (Embrapa). Manual de análises químicas de solos, plantas e fertilizantes. 2. ed. Brasília, DF: Embrapa Informação Tecnológica, 2009.

FERRAZ, R. L. S. et al. Trocas gasosas e eficiência fotoquímica de cultivares de algodoeiro herbáceo sob aplicação de silício foliar. Semina: Ciências Agrárias, v. 35 , n. 2, p. 735-748, 2014.

FREITAS, L. B. et al. Silício na nutrição mineral e acúmulo de alumínio em plantas de arroz de terras altas. Pesquisa Agropecuária Tropical, v. 45, n. 4, p. 440-448, 2015.

GONG, H. J. et al. Effect of silicon on growth of wheat under drought. Journal of Plant Nutrition, v. 26, n. 5, p. 1055-1063, 2003.

HATTORI, T. et al. Application of silicon enhanced drought tolerance in Sorghum bicolor. Plant Physiology, v. 123, n. 4, p. 459-466, 2005.

HUNGRIA, M.; MENDES, I. C. Nitrogen fixation with soybean: the perfect symbiosis? In: BRUIJN, F. J. (Ed.). Biological nitrogen fixations. Ney Jersey: John Wiley \& Sons, 2015. p. 1009-1021.

KAYA, C. et al. Effect of silicon on plant growth and mineral nutrition of maize grown under water-stress conditions. Journal of Plant Nutrition, v. 29, n. 8, p. 14691480, 2006.

KORNDÖRFER, G. H. et al. Análise de silício: solo, planta e fertilizante. Uberlândia: Ed. da UFU, 2004.

KURDALI, F. et al. Growth and nitrogen fixation in silicon and/or potassium fed chickpeas grown under drought and well-watered conditions. Journal of Stress Physiology and Biochemistry, v. 9, n. 3, p. 385-406, 2013.

LOCARNO, M. et al. Influência da adubação silicatada no teor de clorofila em folhas de roseira. Ciência e Agrotecnologia, v. 35, n. 2, p. 287-290, 2011. 
LOPES, J. et al. Nodulação e produção de raízes do estilosantes Mineirão sob efeito de calagem, silicatagem e doses de fósforo. Ciência e Agrotecnologia, v. 35, n. 1, p. 99-107, 2011.

MA, J. F.; YAMAJI, N. Silicon uptake and accumulation in higher plants. Trends in Plant Science, v. 11, n. 8, p. 342-397, 2006.

MEENA, V. D. et al. A case for silicon fertilization to improve crop yields in tropical soils. Proceedings of the National Academy of Sciences, India Section B: Biological Sciences, v. 84, n. 3, p. 505-518, 2014.

NELWAMONDO, A.; DAKORA, F. D. Silicon promotes nodule formation and nodule function in symbiotic cowpea (Vigna unguiculata). The New Phytologist, v. 142, n. 3, p. 463-467, 1999.

NOVAIS, R. F. et al. Ensaio em ambiente controlado. In: OLIVEIRA, A. J. et al. (Coord.). Métodos de pesquisa em fertilidade do solo. Brasília, DF: Embrapa-SEA, 1991. p. 189-253. (Documentos, 3).

PASCUAL, M. B. et al. Silicon addition to soybean (Glycine $\max$ L.) plants alleviate zinc deficiency. Plant Physiology and Biochemistry, v. 108, n. 11, p. 132-138, 2016.

PILON, C. et al. Foliar or soil applications of silicon alleviate water-deficit stress of potato plants. Agronomy Journal, v. 106, n. 6, p. 2325-2334, 2014.

RUPPENTHAL, V. et al. Silicon does not alleviate the adverse effects of drought stress in soybean plants. Semina: Ciências Agrárias, v. 37, n. 6, p. 3941-3954, 2016.

SARTO, M. V. M. et al. Effects of silicate application on soil fertility and wheat yield. Semina: Ciências Agrárias, v. 36, n. 6, p. 4071-4082, 2015.
SHUBERT, K. R.; RYLE, G. J. A. The energy requirements of nodulated legumes. In: SUMMERFIELD, R. J.; BUNTING, A. H. (Eds.). Advances in legume science. Kew: Royal Botanic Gardens, 1980. p. 85-96.

SILVA, M. L. S. et al. Influência do silício na produção e na qualidade de frutos do morangueiro. Semina: Ciências Agrárias, v. 34, n. 6, p. 3411-3424, 2013.

SILVA, O. N. et al. Silicon-induced increase in chlorophyll is modulated by the leaf water potential in two waterdeficient tomato cultivars. Plant, Soil and Environment, v. 58, n. 11, p. 481-486, 2012.

TORESANO-SÁNCHEZ, F. et al. Effect of the application of silicon hydroxide on yield and quality of cherry tomato. Journal of Plant Nutrition, v. 35, n. 4, p. 567-590, 2012.

WANG, S. et al. Silicon enhanced salt tolerance by improving the root water uptake and decreasing the ion toxicity in cucumber. Frontiers in Plant Science, v. 6, n. 759,2015 . Available at: <https://doi.org/10.3389/ fpls.2015.00759>. Access on: 05 Jan. 2018.

WHITE B. et al. Effect of silicate slag application on wheat grown under two nitrogen rates. Plants, v. 6, n. 4, p. 1-14, 2017.

XIE, Z. et al. Effects of silicon on photosynthetic characteristics of maize (Zea mays L.) on alluvial soil. The Scientific World Journal, v. 2014, n. 1, p. 1-6, 2014.

ZANÃO-JÚNIOR, L. A. et al. Growth of rice plants in an Acrustox fertilized with silicon and manganese. Ciência Rural, v. 40, n. 11, p. 2393-2397, 2010.

ZHANG, G. et al. Stimulation of phenolic metabolism by silicon contributes to rice resistance to sheath blight. Journal of Plant Nutrition and Soil Science, v. 176, n. 1, p. 118-124, 2013. 